\title{
Insights on deflation theory
}

\author{
Insights sobre a teoria da deflação
}

ANGEL ASENSIO*

RESUMO: Irving Fisher ofereceu uma teoria "provisória” de deflação de dívidas de grandes depressões em vez de uma teoria totalmente consistente de seu "credo": "Eu digo 'credo' porque, por brevidade, é expressamente expresso dogmaticamente e sem prova. [...] é bastante tentativa" (Fisher, 1933, p. 337). O artigo argumenta que autores proeminentes que se esforçaram para explicar suas ideias dentro do aparelho walrasiano não poderiam fornecer uma teoria consistente de deflação com depressão prolongada. Isto é basicamente porque as forças de mercado desestabilizadoras não podem dominar nesse quadro conceitual. Em contraste, devido à forma como as forças competitivas operam sob incerteza fundamental, a Teoria Geral de Keynes escapa da contradição.

PALAVRAS-CHAVE: Deflação da dívida; depressão; instabilidade; incerteza.

ABSTRACT: Irving Fisher offered a 'tentative' debt-deflation theory of great depressions rather than a fully consistent theory of his 'creed': "I say 'creed' because, for brevity, it is purposely expressed dogmatically and without proof. [...] it is quite tentative" (Fisher 1933, p. 337). The paper argues that prominent authors who strived to explain his ideas within the Walrasian apparatus could not deliver a consistent theory of deflation with protracted depression. This is basically because destabilizing market forces cannot dominate in that conceptual framework. By contrast, owing to the way competitive forces operate under fundamental uncertainty, Keynes' General Theory escapes the contradiction.

KEYWORDS: Debt-deflation; depression; instability; uncertainty.

JEL Classification: B26; E3; E4.

\footnotetext{
* Professor of Economics at the Université Paris XIII, France. E-mail: asensio.angel@univ-paris13.fr. Submitted: 29/November/2016; Approved: 12/May/2017.
} 


\section{INTRODUCTION}

Empirical studies have reported that deflation sometimes goes along with economic depression, and sometimes with economic expansion ('good deflation'), as in the United States, the United Kingdom and Germany in the late $19^{\text {th }}$ century (Michael Bordo et al. 2004). ${ }^{1}$ Although 'good deflation' may be worth studying theoretically, this paper shall centre on 'bad deflation', and more specifically on deflation with protracted depression. The paper discusses how mainstream economics and Keynes' General Theory dealt with 'bad deflation' in the wake of Irving Fisher's famous debt-deflation theory of great depressions.

Irving Fisher's writings (Fisher, 1932, 1933) are indefectibly attached to the conventional view regarding deflation as a demand driven cumulative depression (fig. 1).

Figure 1: Debt-deflation mechanism - The conventional view

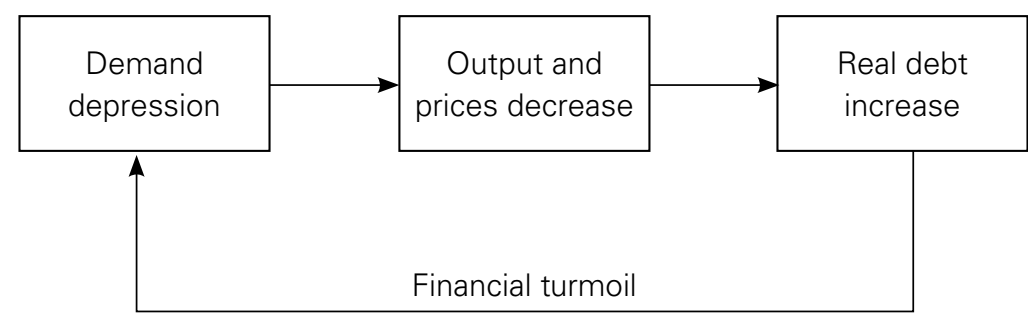

The conventional view, actually, has much more to see with the views expressed in Keynes' General theory (especially in chap. 19 and 22) than with the Fisher's original view, which is better depicted as a supply-driven sequence (fig. 2):

Figure 2: Debt- deflation mechanism - Fisher's simplified sequence

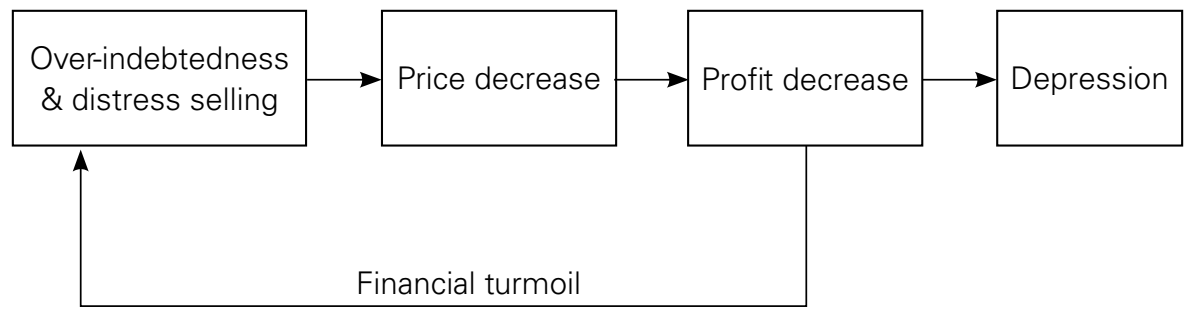

One reason for such a departure might be that Fisher actually did not offer a formal debt-deflation theory of great depressions, or a clear positioning of his views

\footnotetext{
${ }^{1}$ For example, Michael Bordo et al. have observed that " $[\ldots]$ the mild deflation in the period 1870 1896 was accompanied by positive growth in many countries [...]” (Bordo et al., 2004, p. 1).
} 
with respect to the established economic theory of his time. He offered a 'tentative' study on the subject rather than a 'proof' of his 'creed': "I say "creed" because, for brevity, it is purposely expressed dogmatically and without proof. [...] it is quite tentative. It may serve as a challenge to others and as raw material to help them work out a better product" (Fisher 1933, p 337).

In a recent proposal, Cardim de Carvalho (2016) distinguishes depressions from normal cyclical recessions. Depressions are explained as a result of unexpected outcomes that change the parameters that regulated the operation of the economy, thereby leading the system to 'incoherent' behavior. "The most important mechanism spreading and intensifying incoherence is debt deflation. [...] Minsky used the expression 'to sell position to make position' to characterize what asset holders try to do in these circumstances: its end result is widespread financial wealth destruction [...] Wealth destruction, if it is taken too far, makes "normal" recoveries impossible" (Cardim de Carvalho, 2016, pp. 460-461). The present paper focuses specifically on the theoretical foundations of the failure of the "normal" recovery involved in the debt-deflation process. To start with, it sheds light on the Fisher original views (second section) and on the attempt by prominent followers to make sense of Fisher's intuitions within the Walrasian apparatus (third section). It is argued that the explanations offered by those authors lack consistency, basically because the forces involved in the Walrasian theory are at odds with the forces involved in a process of deflation with protracted depression. The paper then explains why Keynes' General Theory escapes the contradiction (fourth section), and how fruitfully Minsky's writings contribute to shed light on the debt-deflation phenomenon (fifth section).

\section{FISHER'S ESSENTIALS BEYOND COMMONPLACES}

Fisher aimed at explaining depressions as part of the business cycle theory. In his view, debt-cycles result from over-indebtedness and over-lending that end when debtors and creditors have 'burned their fingers' and become 'over-cautious'. "Then the pendulum may gradually swing back, caution may again be thrown to the winds, and over-indebtedness again prevail. This swinging back and forth may go on indefinitely, constituting a debt cycle; but, unless some outside force intervenes, each successive swing of the pendulum will have less scope than the last" (Fisher, 1932, p. 12).

According to Fisher, the specificity of a great depression lies in the failure of the swinging back mechanism of the pendulum, which he explains in terms of a persistent or even increasing disequilibrium: ${ }^{2}$

\footnotetext{
2 "Economic theory includes a study both of (a) such imaginary, ideal equilibrium-which may be stable or unstable-and (b) dis-equilibrium. The former is economic statics; the latter, economic dynamics. Socalled cycle theory is merely one part of the study of economic dis-equilibrium" (Fisher, 1933, p. 337).
} 
There may be equilibrium which, though stable, is so delicately poised that, after departure from it beyond certain limits, instability ensues, just as, at first, a stick may bend under strain, ready all the time to bend back, until a certain point is reached, when it breaks. This simile probably applies when a debtor gets 'broke,' or when the breaking of many debtors constitutes a 'crash,' after which there is no coming back to the original equilibrium. To take another simile, such a disaster is somewhat like the 'capsizing' of a ship which, under ordinary conditions, is always near stable equilibrium but which, after being tipped beyond a certain angle, has no longer this tendency to return to equilibrium, but, instead, a tendency to depart further from it. (Fisher 1933, p. 339)

Fisher was aware of existing explanations of economic depressions based on "over-production, under-consumption, over-capacity, price-dislocation, maladjustment between agricultural and industrial prices, over-confidence, over-investment, over-saving, over-spending, and the discrepancy between saving and investment" (Fisher, 1933, p. 340), but the 'great disturbers' in his view were over-indebtedness and deflation:

I venture the opinion, subject to correction on submission of future evidence, that, in the great booms and depressions, each of the above-named factors has played a subordinate role as compared with two dominant factors, namely over-indebtedness to start with and deflation following soon after [...]. Disturbances in these two factors [...] will set up serious disturbances in all, or nearly all, other economic variables. On the other hand, if debt and deflation are absent, other disturbances are powerless to bring on crises comparable in severity to those of 1837 , 1873, or 1929-33. (Fisher, 1933, pp. 340-41)

The 'starters' of over-indebtedness sometimes lies in misfortune or war ('unproductive debts'), but according to Fisher, the over-indebtedness involved in most economic crises is no accident. It results from a) optimistic beliefs of firms regarding the return on investment opportunities, and b) easy money:

Often, if not usually, the opportunity to invest is the result of new inventions, new discoveries, or new business methods. When inventors, or their backers or exploiters, think they can, by borrowing at (say) 6 per cent, make profits of 100 per cent, why should they hesitate to borrow, and keep on borrowing? (Fisher, 1932, pp 45-46)

Sometimes, by coincidence we get all conceivable sorts of starters working in the same direction - such as war, gold discoveries and new processes, new banking systems, with capacity for great credit expansion, great inventions and the rebound from a recent depression. Many of these coincided in the United States in the period 1913-19 and many also in 1926-9. (Fisher, 1932, p. 50) 
Given these starters of over-indebtedness, the core of the Fisher's debt-deflation theory lies in the following 'chain of consequences in nine links':

Assuming, accordingly, that, at some point of time, a state of over-indebtedness exists, this will tend to lead to liquidation, through the alarm either of debtors or creditors or both. Then we may deduce the following chain of consequences in nine links: (1) Debt liquidation leads to distress selling and to (2) Contraction of deposit currency, as bank loans are paid off, and to a slowing down of velocity of circulation. This contraction of deposits and of their velocity, precipitated by distress selling, causes (3) A fall in the level of prices, in other words, a swelling of the dollar. Assuming, as above stated, that this fall of prices is not interfered with by reflation or otherwise, there must be (4) A still greater fall in the net worths of business, precipitating bankruptcies and (5) A like fall in profits, which in a "capitalistic," that is, a private-profit society, leads the concerns which are running at a loss to make (6) A reduction in output, in trade and in employment of labor. These losses, bankruptcies, and unemployment, lead to (7) Pessimism and loss of confidence, which in turn lead to (8) Hoarding and slowing down still more the velocity of circulation.

The above eight changes cause (9) Complicated disturbances in the rates of interest, in particular, a fall in the nominal, or money, rates and a rise in the real, or commodity, rates of interest.

Evidently debt and deflation go far toward explaining a great mass of phenomena in a very simple logical way. (Fisher, 1933, pp. 341-42)

Fisher's 'chain of consequences' can be divided into a basic sequence and an additional aggravating sequence:

\section{Basic sequence}

1. Debt repayments $\rightarrow 2$. Currency contraction $\rightarrow 3$. Price level decrease $\rightarrow$ 4-5. Net-worth and profit decrease $\rightarrow$ 6. Depression

\section{Aggravating sequence}

\section{Loss of confidence $\rightarrow 8$. Hoarding \\ $\rightarrow$ 9. Real interest rates increase}

The first three factors of the basic sequence are 'closely locked together' by distress-selling. Distress selling, aimed at repaying the debts, causes massive debt repayments to the banks and a shrinkage in the quantity of money, hence a decrease in the price level ( $a$ 'swelling of the dollar', as every money unit gets an increasing purchasing power). As price decreases worsen the real burden of outstanding debts, in spite - and because - of the debtors' effort to reduce the debts, the debt-deflation mechanism develops accordingly. 
And when this process starts, it may go on and on, much after the fashion of a vicious circle. First, mass payment by the weaker debtors swells the whole community's dollar, and so weakens the financial position of stronger debtors; whereupon, many of these rush to liquidate too, thus further swelling the dollar, till it weakens the position of still stronger debtors; where-upon many of these in turn rush to liquidate, thus further swelling the dollar and weakening still other debtors - and so on in a vicious circle; or, rather, in a vicious spiral downward - a tail spin - into the trough of depression. (Fisher, 1932, p. 25).

Factors 4 to 6 introduce the Fisher's explanation of the depressive forces involved in the debt deflation mechanism (aggravated by factors 7 to 9). The causation is, on the one hand, that net worth ('the excess of assets over liabilities') "often passes below the zero mark, pushing the owner into business failure" (Fisher, 1932, p. 29), and on the other hand, that "profits are reduced, and often turned into losses" as "receipts fall when prices fall while expenses are less responsive to the assault of deflation than prices are" (Ibid., p. 30). Hence the depression:

In a capitalistic, or private profit, system, it is the profit taker who usually makes the decision as to the rate at which his enterprise is to be run. Therefore, variations in profits, or in the expectation of profits, lead the business man to vary correspondingly the general policy of his enterprise.

When his profits are squeezed too thin for comfort, naturally he will cut his production and release some of his employees, so that the community's general out-put, trade and employment, will take a slump.

That is, current output varies with current profits. (Ibid., pp. 30-31)

\section{DEALING WITH PROTRACTED DEPRESSION: THE FAILURE OF MAINSTREAM ECONOMICS}

Two kinds of rationales have been developed within the Walrasian conceptual framework in order to offer a coherent theory of deflation with protracted depression. The first one explores the possibility of a destabilizing effect associated with the flexibility of wages and prices. The second one focuses on 'nonmonetary' factors.

\section{The basic inconsistency}

Schumpeter's study of the dynamics of the capitalist economy was deeply rooted in Walrasian equilibrium theory (see Schumpeter, 1939, pp. 30-71, especially Equilibrium and the Theoretical Norm, pp. 38-45). His main purpose was to study how innovation and entrepreneurial activity transform equilibrium cycli- 
cally over the long term. ${ }^{3}$ According to Schumpeter (1939), recession is the necessary outcome of the prosperity phase triggered by innovation. It results from the weakening of the credit activity owed to the lower demand for loans as entrepreneurs profit increase. Profit also allows for loan repayments that make money still scarce. This kind of 'Autodeflation' takes part of the adjustment process to the 'new equilibrium' and, therefore, is considered a necessary phase of the business cycle (p. 158). Recession therefore is different from depression in Schumpeter's analysis. Depression refers to 'abnormal liquidation' caused by external factors that may interfere with the business cycle. Schumpeter however thought that a depression should end spontaneously when it has 'run its course', although the new equilibrium should depend on its running (Schumpeter, 1939, pp. 149-150). But Schumpeter thought that "recuperative forces" normally lead the system to a new equilibrium (Schumpeter 1939, pp. 154-155), except in the case of a 'Deep Depression' caused by "exceptionally unfavourable external factors". Schumpeter thereby suggested implicitly a definition of the deep depression phenomenon in terms of a disequilibrium with no tendency to recover 'of itself', but he did not develop a theory of deep deflation.

John Hicks attempted to understand the great depression of the thirties by analyzing the possible destabilizing effect of the wage decrease pointed out in Keynes' General Theory (Chapter 19). To deal with, he focused on the possibility that price expectations were destabilizing as Keynes suggested, but could not make sense of his 'temporary equilibrium' approach to the great depression without assuming some special ad hoc feature with respect to price expectations. This is attested by Rubin (2001), who has investigated Hicks' writings on the subject in depth:

"During the 1930s, Hicks tried to understand the crisis to which capitalist systems were confronted. But unlike most economists of his time, he attempted to apply a Walrasian general equilibrium framework to the situation. The present paper studies how Hicks developed this approach in the last chapters of Value and Capital (1939). Hicks came to argue that the fluctuations of the capitalist system endangered its existence and imagined a theory of the trade cycle giving a major role to expectations and showing the possibility of an economic collapse. The paper analyses the problems raised by this research program in order to explain why Hicks abandoned it while he wrote A Contribution to the Theory of the Trade Cycle (1950). (Rubin, 2011, p. 57).

Rubin (2005) reported that Patinkin also dealt unsuccessfully with the issue

\footnotetext{
${ }^{3}$ Focusing on "Equilibrium economics and the study of business fluctuations", Schumpeter wrote: «We have seen, first of all, that the theory of equilibrium [...], gives us the bare bones of economic logic which, however, abstract or remote from real life it may be, yet renders indispensable service in clearing the ground for rigorous analysis" (Schumpeter 1939, p. 68).
} 
of making sense of the Keynes' views on destabilizing wage and price within the Walras' apparatus.

Patinkin's way out implied two complementary ideas. First, since there was no Keynesian equilibrium and since the Keynesian theory had to assume price flexibility, the only equilibrium concept available was that of Walras. Hence, he abandoned the "inconsistency" scenario and assumed that a Walrasian equilibrium existed. Moreover, since he still believed that the elasticities of investment and savings with regard to the rate of interest were weak, the real balance effect was necessary in order to support this existence assumption. Second, Patinkin was led to the conclusion that "what Keynesian economics claim is that the economic system may be in a position of underemployment disequilibrium" [...] for, by definition, unemployment disappeared in the market-clearing state." (Rubin, 2005, p. 62)

Keynes, however, clearly considered his General Theory a theory of equilibrium, ${ }^{4}$ but Patinkin's acceptance of the Walras theory could only assess involuntary unemployment in a competitive economy as a disequilibrium phenomenon, that is to say, as a temporary departure from equilibrium. Patinkin claimed that there was nevertheless a Keynesian specificity, compared with the classical way of thinking about the adjustment process:

This analysis led Patinkin to lay the emphasis on the duration of the adjustment process towards full employment as the basis of the Keynesian message. The fact that the economy was converging did not prevent involuntary unemployment to exist in the interval between a shock and the return to equilibrium. Whenever this unemployment persisted "more than one year" [...], a "program of direct government investment in public works" [...] was justified. The challenge, then, consisted in showing that an equal degree of price sluggishness had different results in a Classical world and in a Keynesian world. A Classical system would quickly get back to full employment, whereas this would take a long time in a Keynesian system. The specificity of the Keynesian system would not depend on the process rigidity affecting wages and prices, for this rigidity also affected Patinkin's Classical system, but on the elasticity of its aggregate demand function with regard to the level of prices and the rate of interest. (Rubin, 2005, p. 65)

\footnotetext{
4 "I shall argue that the postulates of the classical theory are applicable to a special case only and not to the general case, the situation which it assumes being a limiting point of the possible positions of equilibrium" (Keynes, 1936, p. 3). In fact, The General Theory systematically refers to the concept of equilibrium (disequilibrium is only mentioned twice, in negative terms, while equilibrium is mentioned seventy seven times).
} 
Observe that Patinkin's claim was that it may take longer for the market to get rid of unemployment in 'Patinkin's Keynesian' approach than in the classical view, but in any case unemployment should regress toward full employment (which actually betrays Keynes' view).

Tobin adopted a more radical interpretation of Keynes' theory (Tobin, 1975, also Palley, 2008):

The real issue is not the existence of long-run static equilibrium with unemployment, but the possibility of protracted unemployment which the natural adjustment of a market economy remedy very slowly if at all. So what if, within the recherché rules of the contest, Keynes failed to establish an "underemployment equilibrium"? The phenomena he described are better regarded as disequilibrium dynamics. (Tobin 1975, p. 196)

Tobin's “Keynesian model of recession and depression" rests on the possibility that the well known Pigou and Keynes stabilizing effects of a price decrease (operating through aggregate demand) be reversed or countered. In this case, deflation is destabilizing instead of putting the economy back on its rails. Tobin therefore provided the disequilibrium dynamics suggested by Patinkin with a formal modeling, but beyond the formal aspects he did not solve the inconsistency Patinkin could not escape. First the destabilizing scenario rests on a specific condition about the relative forces operating through deflation. The condition involves the price level effect (Pigou's and Keynes' stabilizing effect), the expected-change in price effect (destabilizing) and the 'response of price expectations to experience' which is destabilizing when strong enough, as in Hicks 'temporary equilibrium' approach to the great depression (extrapolation of the current rate of change in price). ${ }^{5}$ But these effects are taken as exogenous; there is no endogenous force leading to the required condition and, thereby, to a depression. Therefore, instability is just shown to be a possible outcome depending on exogenous parameters. Tobin (1975) provided a way of modeling depression which was not backed with a theoretical discussion of the causes of the destabilizing 'chain of consequences'.

Second, if the parameters of the model meet the condition, the model is defi-

\footnotetext{
${ }^{5}$ Tobin argues that a price decrease has distributional effects between creditors and debtors through the increasing real value of debts, in such a way that the marginal propensity to spend decreases, thereby reversing the Pigou's stabilizing effect. This destabilizing distribution effect sometimes is attributed to Fisher (Rubin, 2011, p. 64; King, p. 431; Tobin, 1980, p. 10). But Fisher (1933) actually neither considered differences in propensities to consume, nor gave much importance to destabilizing redistribution (whereas the destabilizing effect of those factors were pointed out in The General Theory, p. 262).

"This excessive eagerness on the selling side of a market may seem enough to explain how distress selling tends to lower the price level; but it is not the fundamental influence. In fact, the buyer largely gains the spending power which the seller loses, and spending power is what sustains prices. But the stampede liquidation involved in distress selling has a radical effect on the price level, by actually shrinking the volume of the currency - that is, of “deposit currency.” (1932, p. 14).
} 
nitely unstable, which means that its dynamics only depends on how the exogenous parameter move over time and never rejoins full employment but fortuitously. The problem here is that full employment plays a crucial role in determining the "Okun gap" (measured as $\mathrm{Y}^{*}-\mathrm{Y}$ ), hence the deflation of wages and prices, but $\mathrm{Y}^{*}$ is taken as given no matter the length of the disequilibrium, which is clearly a problem insofar as nothing ensures that the disequilibrium will be removed. Tobin only mentions "nonlinear nonmonetary business cycle models like those of M. Kalecki, R. Goodwin, and Sir John Hicks [where] a long depression phase occurs with the economy at a floor. At this floor the capital stock is excessive and gross investment is zero. [...] The depression lasts a long time, while depreciation slowly whittles the capital stock down to the amount needed for floor level production". It is quite surprising that Tobin referred to 'nonmonetary business cycle models' since his purpose was to study the effects of money wage and price deflation. In addition, a decrease in the capital stock 'to the amount needed for floor level production' would certainly decrease the full employment level of output $Y^{*}$ !

\section{Further unfortunate attempts}

Ben Bernanke's Nonmonetary effects of the financial crisis in the propagation of the Great Depression (1983) was about financial intermediation and its capacity to explain the great depression within the orthodox approach. He did not focus on the crisis triggers, but rather on 'the propagation of the Great Depression'. Bernanke claimed that his approach was "complementary to that of Friedman and Schwartz, who emphasized the monetary impact of the bank failures" (Bernanke, 1983 , p. 1). From the monetarist point of view, deflation is interpreted in terms of a money supply contraction which induces an adjustment process. The adjustment process involves a temporary decrease in aggregate demand (as a result of a lower purchasing power of money at previous prices), and then a decrease in money prices, in such a way that the aggregate demand eventually rejoins the full employment level. In the meantime of the adjustment process, money is temporarily non-neutral, which led Friedman and Schwartz (1963) to suggest that the money supply contraction had been the very cause of the great depression. This view however was to be challenged by Bernanke:

There is much support for the monetary view. However, it is not a complete explanation of the link between the financial sector and aggregate output in the 1930s. One problem is that there is no theory of monetary effects on the real economy that can explain protracted non-neutrality. Another is that the reduction of the money supply in this period seems quantitatively insufficient to explain the subsequent falls in output. (Bernanke, 1983, p. 2)

Bernanke's knowledge was deep enough to recognize that the orthodox approach had failed to explain protracted non-neutrality by means of 'monetary effects', 
as experienced by Hicks, Patinkin and Tobin. This is why his challenge was to explain "protracted non neutrality" by means of 'non-monetary', that is, 'real' causes. ${ }^{6}$ To get such a result without departing from the orthodox apparatus, he assumed an incomplete market-structure:

The present paper builds on the Friedman-Schwartz work by considering a [...] way in which the financial crises (in which we include debtor bankruptcies as well as the failures of banks and other lenders) may have affected output. The basic premise is that, because markets for financial claims are incomplete, intermediation between some classes of borrowers and lenders requires nontrivial market-making and information-gathering services. The disruptions of 1930-33 (we shall try to show) reduced the effectiveness of the financial sector as a whole in performing these services. As the real costs of intermediation increased, some borrowers (especially households, farmers, and small firms) found credit to be expensive and difficult to obtain. The effects of' this credit squeeze on aggregate demand helped convert the severe but not unprecedented downturn of 1929-30 into a protracted depression. (Bernanke, 1983, p. 2)

According to Bernanke's explanation, monetary contraction per se could not produce a protracted depression. The protracted depression instead happened because the banks had been impacted in such a way that the 'cost of credit intermediation' (CCI) increased:

[...] institutions, rather than being a "veil", can affect costs of transactions and thus market opportunities and allocations. Institutions which evolve and perform well in normal times may become counterproductive during periods when exogenous shocks or policy mistakes drive the economy off-course. (Bernanke, 1983, p. 37)

More precisely, the increase in the $\mathrm{CCI}$ is explained as follows:

A useful way to think of the 1930-33 debt crisis is as the progressive erosion of borrowers' collateral relative to debt burdens. As the representative borrower became more and more insolvent, banks (and other lenders as well) faced a dilemma. Simple, non-contingent loans faced increasingly higher risks of default; yet a return to the more complex type of contract involved many other costs. Either way, debtor insolvency necessarily raised the CCI for banks. One way for banks to adjust to a higher CCI is to increase the rate that they charge borrowers. This may be counterproductive, however, if higher interest charges increase the risk of default. The more usual response is for banks just not to make loans

\footnotetext{
${ }^{6}$ In this sense, Bernanke's 1983 paper can be associated with the 'Real Business Cycle' literature.
} 
to some people that they might have lent to in better times. [...] This situation precluded many borrowers, even with good "projects", from getting funds [...]. (Bernanke, 1983, p. 17-18)

Bernanke recognized that the propagation mechanism through which the economy is affected may involve the aggregate supply 'in an economic development context', but he rather focused on aggregate demand in the case of the US economy:

The aggregate demand argument is in fact easy to make: A higher cost of credit intermediation for some borrowers (e.g., households and smaller firms) implies that, for a given safe interest rate, these borrowers must face a higher effective cost of credit. (Indeed, they may not be able to borrow at all.) If this higher rate applies to household and small firm borrowing but not to their saving (they may only earn the safe rate on their savings), then the effect of higher borrowing costs is unambiguously to reduce their demands for current-period goods and services. (Bernanke, 1983, p. 21)

Figure 3 shows a simplified effect of CCI on private investment within the traditional 'loanable funds' approach to which Bernanke refers implicitly.

Figure 3: Effects of the $\mathrm{CCl}$ on aggregate investment and saving

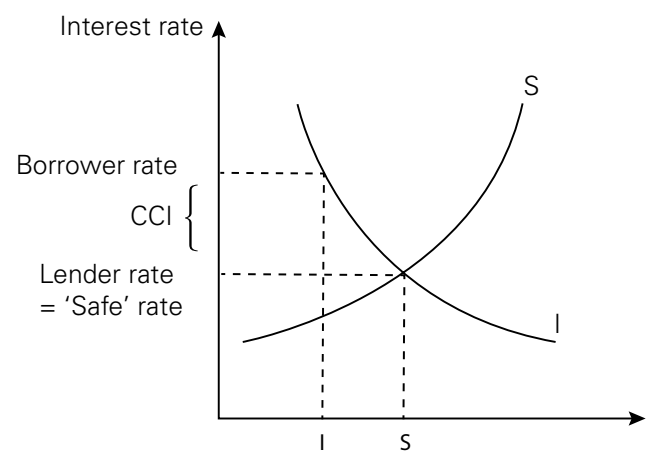

The lasting effect of this abnormal interest rate was explained by the delay necessary for the financial structure to recover:

As a matter of theory, the duration of the credit effects [...] depends on the amount of time it takes to 1) establish new or revive old channels of' credit flow after a major disruption, and 2) rehabilitate insolvent debtors. Since these processes may be difficult and slow, the persistence of non-monetary effects of financial crisis has a plausible basis. (In contrast, persistence of purely monetary effects relies on the slow diffusion of' information or unexplained stickiness of wages and prices.) (Bernanke, 1983, p. 30) 
Bernanke's theory finally offers an explanation based on a real price distortion compared with the first best competitive equilibrium. The problem with his analysis, all the more since 'unexplained stickiness' is not assumed, is that it does not consider the wage and price responses to the growing unemployment caused by an increased CCI! Hicks, Patinkin and Tobin also accounted for an inappropriate interest rate (although in terms of 'liquidity trap'), but they did not overlook that this could only explain a protracted depression provided the wage and price adjustment failed to stabilize the economy. Bernanke's article does not discuss the issue at all, and therefore, does not offer a coherent explanation of protracted depression and unemployment.

Mervyn King's real business cycle approach offers a different explanation of the cause and propagation mechanism of the great depression (King, 1994): "It is the change in the distribution of net worth from debtors to creditors which leads to a fall in demand and output" (King, 1994, p. 422). The model is introduced through the Tobin opposition between the Pigou stabilizing effect and the Fisher's destabilizing effect (Tobin, 1980).

I turn now to the question of how to model debt deflation. The key insight is that provided by Tobin (1980), namely that the marginal propensity to spend from wealth differs between debtors and creditors. The microeconomic analysis of debt deflation, therefore, concerns optimal consumption behaviour under uncertainty. The emphasis will be on the role of precautionary saving. (King, 1994, p. 431)

King's basic idea is that "Distributional shocks associated with changes in the relative asset price produce a non-monotonic aggregate demand function": ${ }^{7}$

Central to the model is the impact of distributional shocks on the aggregate level of consumption. Agents who had borrowed on the expectation of future returns suffer adverse shocks that lead them to consume less and repay debt. Other agents experience offsetting shocks but do not increase consumption by enough to compensate for the reduction of consumption by the first type. In other words, the marginal propensity to consume out of wealth is higher for debtors than for creditors. Consumption responses of this kind reflect precautionary saving. (King, 1994, p. 432)

While Tobin (1975) just provided an analytical discussion of the critical parameter values that make the aggregate demand a positive function of money prices during the depression, King offers microfoundations according to which the diffe-

\footnotetext{
${ }^{7}$ Observe that Keynes (1936, p. 262) had referred to the distributional effects associated with flexible wages and prices well before Tobin and King (further discussed in the next section).
} 
rence in the marginal propensities to consume are endogenous. ${ }^{8}$ It is therefore endogenously that the model delivers a 'non-monotonic aggregate demand function' (the function is positively sloped for low real expected asset prices and negatively sloped for higher real expected asset prices). Owing to non-monotone aggregate demand function, "it is possible, though by no means either necessary or likely, that there are multiple equilibria" when combined with a positively sloped supply function (King 1994, p. 438), as Tobin (1980) already suggested. Hence, changes in the expected relative price of assets (shocks) may trigger stabilizing or destabilizing demand and supply responses depending on the type of the initial equilibrium.

However, although King's article provides Tobin's intuition with orthodox microfoundations, it does not solve the inconsistency issue: according to his business cycle approach, protracted unemployment should make wage and price decrease, but the issue - as in Bernanke's contribution - is not discussed at all, although it was the stumbling block of the Hicks and Patinkin unsuccessful attempts, and although Tobin could not deal with it successfully.

\section{WHAT MAKES KEYNES’ EXPLANATION CONSISTENT}

The inconsistency in the orthodox approaches results, basically, from the endogenous forces involved in the Walrasian representation of the competitive economy: by rising unemployment, economic depressions involve downward pressure on wages, which tends to remove unemployment and stop the depression, rather than to make the depression stronger and the wages lower. By contrast, wage decreases do not tend to remove unemployment in Keynes' General Theory, which removes the inconsistency issue:

"If [...] money-wages were to fall without limit whenever there was a tendency for less than full employment, $[. .$.$] there would be no resting-$ -place below full employment until either the rate of interest was incapable of falling further or wages were zero. In fact we must have some factor, the value of which in terms of money is, if not fixed, at least sticky, to give us any stability of values in a monetary system.' (Keynes 1936, 303-304).

\footnotetext{
${ }^{8}$ Although King does not make explicit reference to incomplete market, his microfoundations clearly refer to: "The precautionary saving motive means that an increase in uncertainty about future endowments leads households to save more in order to provide for a rainy day. [...] The motivation for recognising the importance of deferred endowments is the existence of illiquid assets for which use or control is not easy to separate from ownership, and the returns on which are not verifiable [...]. The illiquid nature of the assets is crucial, because it means that asset price risk is uninsurable" (King, 1994, p. 433). Note that the 'uninsurable risks' here only involves the kind of micro uncertainty resulting from incomplete markets. It has nothing to do with the Keynes fundamental uncertainty. In King's model there is 'no aggregate uncertainty at all' (King, 1994, p. 420) because the distributional micro shocks compensate for one another.
} 
As argued in Asensio (2012), mainstream economists fail to understand the point because they overlook the pervasive effects of the fundamental uncertainty on individuals' decision-making and on the resulting aggregate outcome under competitive conditions. As a consequence, wage rigidity is seen as an obstacle to full employment (as if wage flexibility would ensure full employment in Keynes' theory), whereas it is kind of an endogenous 'institutional stabilizer' (Asensio 2012, pp. 22-28). When a depression goes along with a weakening of the institutional stabilizers, the decrease in wages and prices is likely to degenerate into a cumulative depression of the effective demand through a series of effects discussed in chapter 19 of The General Theory. Some negative effects operate through expectations of a further decrease in prices (which weakens the marginal efficiency of capital and inducement to invest (Keynes, 1936, pp. 263-271). Other effects operate through real income redistribution and the related change in the propensity to consume:

A reduction of money-wages will somewhat reduce prices. It will, therefore, involve some redistribution of real income (a) from wage-earners to other factors entering into marginal prime cost whose remuneration has not been reduced, and (b) from entrepreneurs to rentiers to whom a certain income fixed in terms of money has been guaranteed. [...] The transfer from wage-earners to other factors is likely to diminish the propensity to consume. The effect of the transfer from entrepreneurs to rentiers is more open to doubt. But if rentiers represent on the whole the richer section of the community and those whose standard of life is least flexible, then the effect of this also will be unfavourable. (Keynes, 1936, p. 262)

Keynes also pointed the debt-deflation issue in terms of an over-indebtedness caused by the decrease in wages and prices:

Indeed if the fall of wages and prices goes far, the embarrassment of those entrepreneurs who are heavily indebted may soon reach the point of insolvency, - with severely adverse effects on investment. Moreover the effect of the lower price-level on the real burden of the national debt and hence on taxation is likely to prove very adverse to business confidence. (Keynes, 1936, p. 264)

It transpires, therefore, that the concept of a cumulative depression does not conflict with the Keynes theory. Keynes actually regarded the phenomenon of the crisis more broadly as part of the theory of the trade cycle outlined in chapter 22 of The General Theory:

There is, however, another characteristic of what we call the trade cycle which our explanation must cover if it is to be adequate; namely, the phenomenon of the crisis - the fact that the substitution of a down- 
ward for an upward tendency often takes place suddenly and violently, whereas there is, as a rule, no such sharp turning-point when an upward is substituted for a downward tendency. (Keynes, 1936, p. 314; original emphasis)

Two types of events may contribute to the downturn in The General Theory: an increase in interest rates and/or a decrease in the marginal efficiency of capital, but the most plausible one, according to Keynes, is the latter: "The trade cycle is best regarded, I think, as being occasioned by a cyclical change in the marginal efficiency of capital, though complicated and often aggravated by associated changes in the other significant short-period variables of the economic system" (Keynes,1936, p. 313). When the investment wave ends, that is, when the marginal efficiency of capital no longer supports a sufficient inducement to invest, the downturn of the firms' expectations weakens the aggregate demand dynamics. ${ }^{9}$ Then, unsold inventories tend to stop the investment wave and to provoke an abrupt slump. Hence, depressive phases are likely to be more brutal than expansionary ones. As the pre-crisis period is boosted by optimistic expectations, there is a moderate liquidity preference and, therefore, borrowers obtain financing at relatively low interest rates. It is after the slowdown and the related trouble in asset markets that the liquidity preference and the long-term interest rates are likely to increase, thereby magnifying the slump. While the recovery phases may spread over time because of the difficulty of enhancing the state of confidence, the latter is likely to fall sharply in the downturn.

The later stages of the boom are characterised by optimistic expectations as to the future yield of capital-goods sufficiently strong to offset their growing abundance and their rising costs of production and, probably, a rise in the rate of interest also. It is of the nature of organised investment markets, under the influence of purchasers largely ignorant of what they are buying and of speculators who are more concerned with forecasting the next shift of market sentiment than with a reasonable estimate of the future yield of capital-assets, that, when disillusion falls upon an over-optimistic and over-bought market, it should fall with sudden and even catastrophic force. (Keynes, 1936, pp. 315-316)

Observe that Keynes associates the downturn to 'disillusion falls upon an over-optimistic and over-bought market', which is not irrational behavior under the fundamental uncertainty, as the risk attached to debts and assets cannot be objectively quantified.

\footnotetext{
${ }^{9}$ Remember that the marginal efficiency of capital decreases with the level of investment, first, because of the diminishing return on capital, and second, because of the concomitant increase in the price of capital goods (Keynes, 1936, p. 136).
} 


\section{ENDOGENOUS OVER-INDEBTEDNESS AND DEBT-DEFLATION ACCORDING TO MINSKY}

Minsky's views on financial instability also focused on endogenous forces capable of threatening the sustainability of the growth process. On this issue, Minsky was very much inspired by Keynes' General Theory, which helped him filling the Fisher's theoretical lacunae: ${ }^{10}$

In his financial instability interpretations of Keynesian theory, Minsky developed a theory which closely integrated liability structures with system behavior. This filled the lacunae in the Fisherian debt deflation theory of great depression [...]. (Minsky, 1994, p. 3)

Minsky's was essentially interested in explaining the process of over-indebtedness and "how the actions of bankers, businessmen and households as owners and managers of portfolios generated the process" (Minsky, 1994, p. 2). He was not directly concerned with the 'propagation mechanism', that is, the depressive effects of the financial crisis with respect to effective demand, output and employment. His central purpose and original contribution were about the endogenous triggering of the financial crisis and how the 'institutional environment' interacted with it (sometimes being able to cope with it), not about the proper path of the subsequent depression.

According to Minsky (1981), the financial structure becomes more fragile because of the financial innovations of profit-making financial institutions that take place during the period of good times (the well known paradox of tranquility according to which stability is destabilizing):

In any money using economy with debts there will be pockets of money that are committed by the holder to payments that will take place in the (near) future. These "pocket of money" are raw material for short-term debt financing. Innovators in financial markets develop new ways of using cash or of getting cash for both long- and short-term financing. Thus, over a period of good times short-term debt increases relative to the flow of cash in the form of gross profits. As short-term debt becomes an increasing part of the debt structure, finance becomes increasingly speculative, in that a larger portion of maturing debt can be paid off only by issuing new debt. In these circumstances, the viability of borrowers becomes increasingly dependent upon the availability of funds through various markets. (Minsky, 1981, pp, 11-12)

\footnotetext{
${ }^{10}$ In this quotation, Minsky refers to his own 'Debt Deflation Processes in Today's Institutional Environment” (Minsky, 1981).
} 
In this context, two kinds of events can operate as triggers of the debt deflation process: a rise in interest rates and a shortfall of profits:

The margins of safety that Keynes referred to exist in an excess of cash receipts over cash payment commitments, the excess of the value of assets over liabilities and holdings of cash are liquid assets. A rise in interest rates will lead to a decrease in the excess of cash receipt [...]. If over time debt financing of positions increases, then the margin of safety in both cash flows and asset values that makes the continued normal functioning of a system of debt possible can disappear as a result of a not unusual rise in interest rates, or alternatively of a not unusual shortfall of profits. The evolution of the debt structure can lead to a situation in which a not unusual event triggers both a desire to reduce debt and an unwillingness to debt finance new endeavors. (Minsky, 1981, p. 7)

The emphasis on 'not unusual' events refers to the fact that the crisis does not depend properly on such events, but on the prior endogenous increase in speculative finance. The crisis subsequently happens as a result of an endogenous increase in interest rates:

"It is clear in theory -and it has been observed in the economy the larger the dependence upon speculative and Ponzi finance the greater the likelihood that a sharp run up in short-term interest rates will occur. Once rapid increases in short-term interest rates take place, the expected gain from carrying assets decreases: this leads units to make their payments by selling out positions. A collapse of asset values as a result of excess supply in markets or the inability of units that have maturing debts to make payments are the triggers of a debt deflation process. (Minsky, 1981, pp. 13-14)

It is worth noting that, in Minsky's argument, the very cause of the crisis is not the triggering factor per se, but the increased fragility that allows for a 'not unusual event' to be capable of triggering the crisis.

The remainder of Minsky's 1981 article explains why potential debt-deflation processes did not develop according to the Fisher's chain of consequences in 'today's institutional environment', but instead gave rise to the phenomenon of stagflation:

The repercussions of the initial inability to meet payments is contained only as some form of concessionary finance emerges; either from debt holding organizations of from without. In today's economy concessionary finance almost always involves the Central Bank either directly or indirectly. The Central Bank's actions or interventions almost always involve the introduction of Central Bank liabilities - reserve money- into the economy, either in the refinancing process or to ease the burden of the proximate refinancing organization" (Minsky, 1981, p. 14) 
The argument is interesting in the perspective of the present contribution because it brings material on how endogenous institutional responses intervene to compensate for the market destabilizing forces. But Minsky also was aware of the possible failure of the monetary-institutions response:

In particular, over a protracted period of good times, capitalist economies tend to move from a financial structure dominated by hedge finance units to a structure in which there is large weight to units engaged in speculative and Ponzi finance. Furthermore, if an economy with a sizeable body of speculative financial units is in an inflationary state, and the authorities attempt to exorcise inflation by monetary constraint, then speculative units will become Ponzi units and the net worth of previously Ponzi units will quickly evaporate. Consequently, units with cash flow shortfalls will be forced to try to make position by selling out position. This is likely to lead to a collapse of asset values. (Minsky, 1992, p. 8)

\section{CONCLUSION}

Fisher's tentative debt-deflation theory of great depressions did not offer a fully consistent explanation of the phenomenon, but given the broad appeal of his theory, prominent followers strived at making sense of the Fisher ideas within the Walrasian apparatus. Contributions by James Tobin, Don Patinkin, John Hicks, Ben Bernanke and Mervyn King have been examined in the first part of this paper. None of them got to offer a consistent theory of deflation cum protracted depression. This is because such disruption is fundamentally inconsistent with the orthodox economics conceptual framework. The second part of the paper has argued that endogenous over-indebtedness, destabilizing deflation and the central role of finance are fully consistent with Keynes' General Theory and Minsky's Financial Instability Hypothesis. Thanks to the recognition of fundamental uncertainty, Keynes and Minsky provided macroeconomic theory with a consistent approach to endogenous debt-deflation cum protracted economic depression.

\section{REFERENCES}

Asensio, A. (2012), “On Keynes' Seminal Innovation and Related Essential Features: Revisiting the Notion of Equilibrium in The General Theory.” In T. Cate (ed.), Keynes' General Theory: 75 Years Later. Northampton: Edward Elgar.

Bordo, M.D, J.L. Lane, A. Redish (2004) "Good versus bad deflation, lessons from the gold standard era". NBER Working Paper 10329.

http://www.nber.org/papers/w10329.pdf. Accessed November 2016

Bernanke, B (1983), Nonmonetary effects of the financial crisis in the propagation of the Great Depression. NBER Working Paper No. 1054. Also in: American Economic Review 73(3): 257-276.

Cardim de Carvalho, F.J. (2016) "Is this 'it'? An outline of a theory of depressions". Brazilian Journal of Political Economy, 36 (3): 451-469. 
Fisher, I. (1932) Booms and Depressions. Adelphi Company, Binghamton, New York.

Fisher, I. (1933) “The Debt-Deflation Theory of Great Depressions”. Econometrica, 1(4): 337-357.

Keynes, J.M. (1936) The General Theory of Employment, Interest and Money. MacMillan, London.

King, M. (1994) "Debt-Deflation: Theory and Evidence". European Economic Review, 38: 419-45.

Kregel, J.A. (1976) "Economic methodology in the face of uncertainty: the modelling methods of Keynes and the Post- Keynesians". Economic Journal, 86(342): 209-25.

Minsky, H.P. (1975) John Maynard Keynes. Columbia University Press.

Minsky, H.P. (1981) “Debt Deflation Processes in Today's Institutional Environment”. Hyman P. Minsky Archive, Paper 229.

http://digitalcommons.bard.edu/hm_archive/229. Accessed November 2016

Minsky, H.P. (1986) Stabilizing an Unstable Economy. Yale University Press, New Haven, CT.

Minsky, H.P. (1992) “The Financial Instability Hypothesis”. Working paper, Jerome Levy Economics Institute of Bard College, no. 74.

http://www.levyinstitute.org/pubs/wp74.pdf. Accessed November 2016

Minsky, H.P. (1994) “The Debt Deflation Theory of Great Depressions”. Hyman P. Minsky Archive, Paper 159.

http://digitalcommons.bard.edu/hm_archive/159. Accessed November 2016

Palley, T. (2008) "Keynesian models of deflation and depression revisited". Journal of Economic Behavior \& Organization, 68: 167-177.

Rubin, G. (2005) "Patinkin and the Pigou effect: or how a Keynesian came to accept an anti-Keynesian argument". The European Journal of the History of Economic Thought, 12(1): 47-72.

Rubin, G. (2011) “Hicks et l'économie de la dépression”. Recherches Economiques de Louvain, 77(4): 57-87.

Schumpeter, J. (1939) Business Cycles. A Theoretical, Historical, and Statistical Analysis of the Capitalist Process. McGraw-Hill: New York.

Tobin, J. (1975) "Keynesian models of recession and depression". American Economic Review, 65: 195-202.

Tobin, J. (1980) Asset Accumulation and Economic Activity. Chicago University Press. 